\title{
L'écoulement dans des canaux rectangulaires présentant une section rétrécie
}

\author{
Flow in rectangular channels \\ with lateral constriction plates
}

\author{
PAR H.-R. VALIENTINE
}

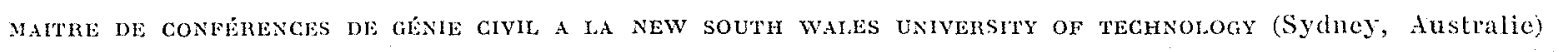
SENIOR LECTURER IN CIVIL ENGiNEERING NEW SOUTH WALES UNIVIIISTTY OF TECHNOJociY (Sydncy, Australie)

Les caractéristiques de l'écoulement dans un canal rectangulaire muni d'écrans latéraux d'étranglement à arête vive, placés symétriquement et perpendiculairement à l'écoulement, sont étudiées dans un canal à faible pente. Le débit $Q$ est en rapport avec la profondeur en amont $\mathrm{y}_{1}$, par l'équation $O=\mathrm{Cby}_{1} 3 / 2$, dans laquelle b est la largeur da passage et $C$ un coefficient expérimental qui tient compte du coefficient d'étranglement et dn nombre de Froude de l'écoulement non étranglé. Les valeurs de $C$ sont établies pour des nombres de Froude jus$q u u^{\prime} \dot{a} 2,1$ et pour un coefficient d'étranglement jusqu'à $95 \%$.

Les conditions dans lesquelles l'insertion des écrans d'étranglement entraine une augmentation de la profondeur en amont sont étudiées et l'importance de cette augmentation est évaluée.

\begin{abstract}
Characteristics of flow in a rectangular channel with sharp edged lateral constriction plates placed symmetrically, normal to the flow, are examined in a small tilting channel. The flow rate, $Q$, is related to the upstream depth $\mathrm{y}_{1}$, by means of a discharge equation $Q=$ Cby $_{1} 3 / 2$, where b is the width of opening and $C$ is an experimental coefficient which depends upon the constriction ratio and the Froude Number of the unconstricted flow. The values of $C$ are established for Froude Numbers up to 2.1 and constriction ratios up to $95 \%$.
\end{abstract}

The conditions under which insertion of constriction plates produces an increase in upstream depth are investigated and the extent of the increase is coaluated.

\section{NO'TATIONS}

B : largeur du canal;

$b \quad$ : largeur de l'ouverture;

C, $\mathrm{C}_{d}$ : coefficients de débit;

$\mathrm{E} \quad$ : énergie spécifique $\left[y+\left(\mathrm{V}^{2} / 2 g\right)\right]$;

$\Delta \mathrm{E} \quad$ : perte de charge totale;

$\Delta \mathrm{E}_{c} \quad$ : perte de charge au niveau de la contraction;

$\Delta \mathrm{E}_{c} \quad$ : perte de charge par élargissement brusque;

$F_{0} \quad:$ nombre de Froude de l'écoulement initial;

$f_{1}, f_{2}, f_{3}$ : symboles de fonctions;

$g \quad$ : accélération due à la pesanteur;

$m$ : coefficient de contraction;

Q : débit total;

$\mathrm{S}_{0} \quad$ : pente du fond; width of channel;

width of opening;

coefficients of discharge;

specific energy $=y+\left(\mathrm{V}^{2} / 2 g\right)$;

total loss of specific energy;

loss of specific energy during contraction; loss of specific energy during expansion; unconstricted flow Froude Number;

function signs; gravitational acceleration; contraction ratio;

total discharge;

bed slope; 
$S_{e} \quad$ : pente du lit pour un écoulement en régime uniforme critique;

$Y_{0}$ : vitesse moyenne dans l'écoulement uniforme initial;

$Y_{1} \quad$ : vitesse moyenne à la section 1 ;

$\mathrm{Y} \quad$ : profondeur ;

$Y_{c} \quad$ : profondeur crilique.

\section{Introduction}

L'étude de l'écoulement à travers des rétrécissements latéraux dans les canaux s'apparente d'ordinaire à la délermination des caractéristiques des sections de jaugeage ou de l'écoulement sous les ponts. Aussi, les expériences entreprises à ce sujet ont-elles été généralement limitées aux conditions d'écoulement les plus couramment rencontrées sur le terrain. Les recherches les plus générales effectuées ces dernières années dans ce'domaine ont été celles de Yarnell [1]; elles fournirent un grand nombre de données relatives à l'écoulement entre des piles de pont. D'autres recherches postérieures $[2,3]$ se limitèrent au cas des ponts où l'écoulement dảns la section de contrôle était de type fluvial, les essais ayant lien sur fond horizontal.

Pratiquement, on peut dire que tontes les formules établies jusqu’à présent, reliant le débit à la profondeur et aux caractéristiques du rétrécissement, font intervenir, comme profondeur, la profondeur moyenne dans la section « la plus contractée $»$, ou au voisinage de celle-ci. Cette façon d'aborder la question peut en général se justifier dans les conditions couramment rencontrées sur le terrain; elle ne convient pas lorsqu'il s'agit de traiter dans le cas général le problème des écoulements à travers des sections rétrécies à parois verticales. Parfois, le jet débouchant de la fente prend plus ou moins l'aspect d'une nappe d'eau verticale, soumise à la pression atmosphérique sur une grande partie de sa hauteur; l'hypothèse d'une répartition hydrostatique des pressions à l'intérieur du jet ne peut pas se justifier.

A la New South Wales University of Technology, une étude du cas le plus général est actuellement en cours; quelques-uns des résutats déjà obtenus ont un intérêt théorique et pourraient être utilisés pratiquement par des ingénieurs s'intéressant à certains cas d'écoulement à traver's une section rétrécie.

\section{Considérations générales}

Il est possible d'aborder l'étude des relations existant entre la profondeur, les caractéristiques bed slope for uniform eritical depth flow;

mean unconstricted uniform flow relocity;

moan velocity al section 1 ;

depth of flow;

critical depth.

\section{Introduction}

Investigations of flow through lateral constrictions in channels have usually been associated with the determination of the characteristics of measuring flumes or bridge waterway areas. The experimental work has therefore been restricted largely to conditions of flow most likely to be met with in the field. The most general study in recent years was that of Yarnell [1] which provided a wealth of data on flow between bridge piers. Later comprehensive invesligations $[2,3]$, were limited to cases relating to bridges in which the flow at the constricted section was subcritical, or trancuil, and the tests were conducted in a horizontal chamnel.

Practically all of the formulae so far developed, relating the discharge to depth of flow and constriction characteristics, contain as the reference depth, the mean depth of flow at or near the "most contracted" section. Such an approach, while generally adequate for conditions usually met with in the field, is not satisfactory for a general approach to the problem of flows through vertical slots in channels. In some such flows, the jet issues from the slot more or less as a vertical sheet of water, at atmospheric pressure for a large part of its depth, and the assumption of hydrostatic pressure distribution in the jet is not justifiable.

A study of the more general case is being made at the New South Wales University of Technology and some of the results to date are of theoretical interest and may be of practical value to engineers concerned with certain problems of slot flow.

\section{General Considerations}

The inter-relationship of depth, flow characteristics and boundary geometry' can be investigated by consideration of the differences in specific energy content along the channel be- 
de l'écoulement et les limites géométriques, en comparant les quanlités d'énergie spécifique véhiculées le long du canal dans des écoulements de même débit mais comportant ou non un rétrécissement. On évite ainsi l'introduction précise de la perte de charge uniforme de l'écoulement non perturbé.

L'étude générale de la question soulève deux problèmes d'intérêt pratique :

a) L'établissement d'une formule de débit;

b) La détermination de la variation de la profondeur amont (effet de remous) causée par la présence du rétrécissement.

La figure 1 représente sous forme schématique tween unconstricted and constricted flows of the same discharge. Such a procedure enables a detailed consideration of the uniform energy loss in the unconstricted flow to be avoided.

Two related problems of practical interest in the general study are:

(a) the establishment of a discharge equation; and

(b) the determination of the change in upstream depth (the "backwater" effect) produced by the constriction.

Figure 1 shows diagrammatically the changes in depth and specific energy resulting from the

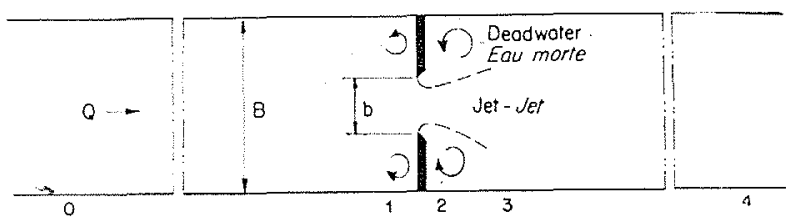

a) Plon - Plan
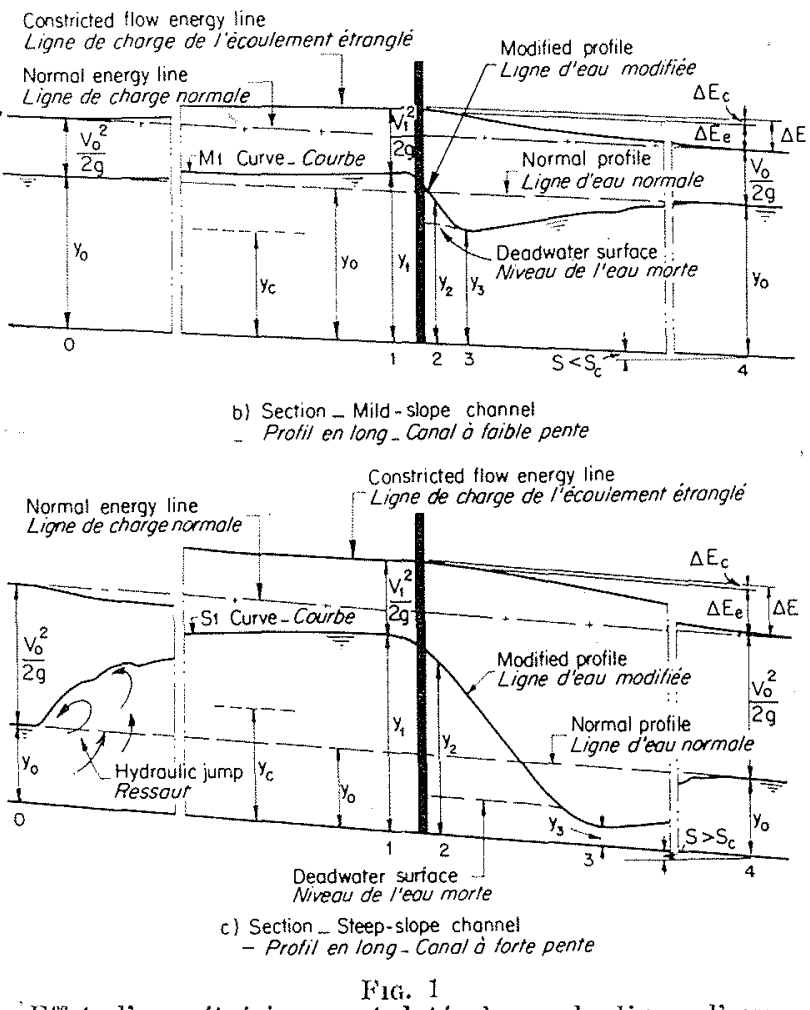

Effet d'un rétrécissement latéral sur la ligne d'eau et les pertes de charge.

fffect of lateral constriction on profite and energy gradient.

les variations de profondeur et d'énergie spécifique causées par l'introduction dans un canal rectangulaire, perpendiculairement à l'écoulement, d'une plaque verticale à arête vive déterminant un rétrécissement. On peut s'expliquer insertion of a knife-edged vertical slot constricting plate, normal to the flow, in a rectangular channel. The changes can be explained in general terms as follows. Sections 0 and 4 are to be considered as sufficienlly distant from the 
de la façon suivante, en termes généraux, les modifications survenues :

Les sections 0 et 4 peuvent être considérées comme assez éloignées du rétrécissement pour que l'écoulement y soit pratiquement uniforme. Comme la vitesse dans la section rétrécie dépasse celle dans la section 1 où la profondeur est maximum, il se produit une légère perte d'énergie spécifique $\Delta \mathrm{E}_{c}$ due à ce que, dans la zone rétrécie, il $y$ a augmentation des pertes par résistance. superficielle. La grande vitesse, avec la turbulence qui en résulte dans l'expansion latérale et verticale du courant entre les sections 2 et 4 , se traduit par une forte perte d'énergie spécifique par élargissement brusque $\Delta \mathrm{E}_{c}$. La perte totale d'énergie spécifique entre les sections 1 et 4 est de :

$$
\Delta \mathrm{E}=\Delta \mathrm{E}_{c}+\Delta \mathrm{E}_{e}
$$

Ce surplus d'énergie, que l'on observe dans la section 1 relativement à l'écoulement non rétréci, est dû à la diminution de l'ensemble des pertes de charge par unité de longueur en amont de la section 1. L'accroissement de profondeur de l'eau à l'approche de la section rétrécie est accompagné par, une réduction correspondante de la vitesse, donc aussi des pertes de charge par frottement. La charge dépasse celle qui correspond à l'écoulement non rétréci, d'une quantité totale atteignant $\Delta \mathrm{E}$ à la section 1. Dans le cas d'un canal en pente douce, le profil de la surface de l'eau en amont est une courbe $\mathbf{M}_{1}$ [4]. Si le canal est à pente raide, le profil est une courbe $S_{1}$ succédant à un ressaut hydraulique à condition que la profondeur $y_{1}$ dépasse la profondeur correspondant à l'entretien du ressaut. Si l'on crée un ressaut artificiel et si la profondeur conjuguée dépasse $y_{1}$, le ressaut sera chassé vers l'aval et créera un front d'onde stationnaire partant du bord du rétrécissement vers l'aval en forme de V. En amont de la partie rétrécie, l'écoulement sera entièrement torrentiel, comme dans un canal non rétréci (fig. 2).

L'eau traverse la partie rétrécie (fig. 1) et sort sous forme d'un jet dont la contraction la plus forte se situe un peu au-delà des arêtes de la section rétrécie. Selon la vitesse de l'écoulement, la pente du canal et la longueur de la partie rétrécie, ce jet peut être noyé entièrement ou partiellement dans la zone d'eau morte qui l'entoure au voisinage de la surface de la plaque; elle peut aussi être à peu près entièrement soustraite à tout effet latéral sur une grande distance et présenter à la sortie l'aspect d'une nappe verticale ayant une pente superficielle appréciable. La section transversale subit alors une forte altération entre les profils 2 et 3 , for- constriction for flows at those sections to be substantially uniform. The velocity in the contracting section of the sow being higher than that at Section 1, the section of maximum depth, there is a slight loss of specific energy, $\Delta \mathrm{E}_{\theta}$, owing to increased surface resistance loss in the region of the contracting flow. The high velocity and subsequent turbulence in the lateral and vertical expansion of the flow between Sections 2 and 4 results in a considerable specific energy loss of expansion, $\Delta \mathrm{E}_{c}$. The total loss of specific energy between Sections 1 and 4 is:

$$
\Delta \mathrm{E}=\Delta \mathrm{E}_{c}+\Delta \mathrm{E}_{\text {, }}
$$

This surplus energy at Section 1 over that for unconstricted flow is provided by a decrease in the space rate of total energy loss upstream of Section 1. The increase in the depth of the water as it approaches the constriction is accompanied by a corresponding decrease in velocity and therefore in the surface resistance energy loss rate. The energy gradient rises above that of the unrestricted flow, the total rise at Section 1 being $\Delta \mathrm{E}$. In the case of a mild-slope channel, the upstream water surface profile is an $M_{1}$ curve [4]. In the case of a steep-slope

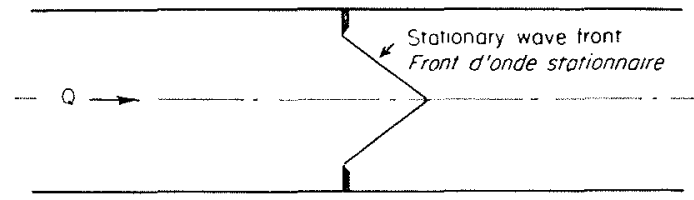

a) Plon -

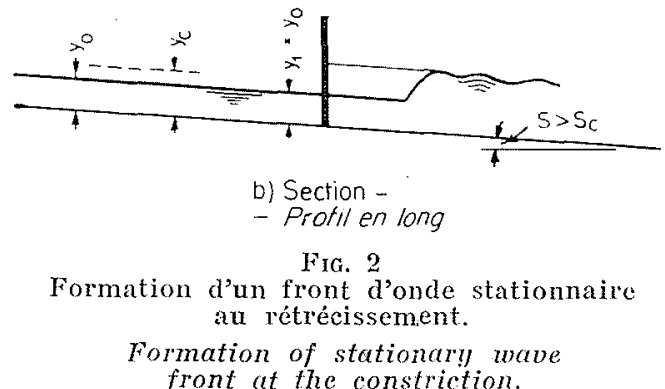

channel, the profile is an $\mathrm{S}_{1}$ curve, following a hydraulic jump, provided that the depth $y_{1}$ exceeds the sequent depth required to sustain the jump. If a jump is established artificially and its sequent depth exceeds $y_{1}$, the jump will travel downstream to produce a stationary wave front, extending from the edges of the constriction downstream in the form of a $V$. The flow upstream from the constriction will be wholly supercritical as in the unconstricted channel (fig. 2).

The flow through the constriction (fig. 1) issues as a jet which suffers its maximum late- 
mant à la partie supérieure un bourrelet, lequel va en s'évasant à mesure que la nappe perd de sa hauteur. A la section 3 , le jet s'évase latéralement et perd son individualité pour se fondre dans un écoulement à trois dimensions. C'est une des raisons pour lesquelles on ne saurait rapporter à la profondeur $y_{3}$ l'équation générale exprimant un débit. La profondeur amont maximum $y_{1}$ intervient alors comme profondeur de référence.

\section{L'équation du débit}

L'analyse physique de l'écoulement au voisinage du rétrécissement, basce sur un bilan énergétique, se complique du fait de la combinaison des contractions latérale et verticale de la nappe et aussi par le degré plus ou moins grand du noyage du jet. D'autre part, il n'est guèe possible d'attaquer le problème par les quantités de mouvement, car nous ne possédons pas une notion exacte des forces extérieures entrant en jeu en aval de la partie rétrécie.

L'analyse dimensionnelle, dans l'hypothèse :

$$
\mathrm{Q}=f_{1}\left(y_{0}, y_{1} \mathrm{~B}, b, g\right)
$$

fournit la relation :

$$
\frac{\mathrm{Q}}{\sqrt{g} b y_{1}^{3 / 2}}=f_{2}\left(\frac{\mathrm{Q}}{\sqrt{g \mathrm{~B} y_{0}{ }^{3 / 2}}}, \frac{b}{\mathrm{~B}}, \frac{y_{0}}{\mathrm{~B}}\right)
$$

En substituant :

$\mathrm{F}_{0}=\frac{\mathrm{V}_{0}}{\sqrt{g} y_{0}}$ à $\frac{\mathrm{Q}}{\sqrt{g} \mathrm{~B} y_{0}^{3 / 2}}$ et $m=\frac{\mathrm{B}-b}{\mathrm{~B}}$ à $\frac{b}{\mathrm{~B}}$

on a :

$$
\mathrm{Q}=\mathrm{C} b y_{1}^{3 / 2}
$$

C désignant:

$$
f_{:}\left(\mathrm{F}_{0}, m, \frac{y_{0}}{\mathrm{~B}}\right)
$$

On pourrait aussi écrire:

$$
\mathrm{Q}=\mathrm{C}_{d} b \sqrt{ } 2 g y_{1}^{3 / 2}
$$

en introduisant un coefficient non dimensionnel de débit :

$$
\mathrm{C}_{d}=\frac{\mathrm{C}}{\sqrt{2 g}}
$$

Le coefficient de débit se présente donc comme fonction du paramètre $\left(F_{0}\right)$ caractérisant l'écoulement non rétréci, des caractéristiques géométriques de la partie rétrécie $(m)$ et de l'écoule- ral contraction a short distance from the plate edges. Depending upon the flow rate, the channel slope and the extent of constriction, the jet may be completely or partally drowned by the "dead" water on each side, adjacent to the plate; or it may" be almost completely free of side effects for a considerable distance, issuing initially as a vertical sheet, whit appreciable surface slope. In the latter case, the cross section suffers considerable change in form between sections 2 and 3, dereloping a flange at the top surface which broadens as the surface height decreases. At section 3 , this jet spreads laterally and loses its identity in a three-dimensional flow pattern. This is one reason for the depth $y_{3}$ being quite unsatisfactory as a reference depth for a general discharge equation. The maximum upstream depth $y_{1}$ is suitable as a reference depth.

\section{The Discharge Equation}

Physical analysis of the flow at the constriction by the energy approach is complicated by the occurrence of vertical as well as lateral contraction and by the variable extent of drowning of the jet. The momentum approach is restricted by lack of sufficiently reliable knowledge of boundary forces in the region downstream from the constriction.

Dimensional analysis, based upon the assumption that :

$$
\mathrm{Q}=f_{1}\left(y_{0}, y_{1} \mathrm{~B}, b, g\right)
$$

yields the relationship:

$$
\frac{\mathrm{Q}}{\sqrt{g} b y_{1}^{3 / 2}}=f_{2}\left(\frac{\mathrm{Q}}{\sqrt{g} \mathrm{~B} y_{0}{ }^{3 / 2}}, \frac{b}{\mathrm{~B}}, \frac{y_{0}}{\mathrm{~B}}\right)
$$

Writing:

$F_{0}=\frac{V_{11}}{\sqrt{g} y_{0}}$ for $\frac{Q}{\sqrt{g} \mathrm{~B} y_{0}{ }^{3 / 2}}$ and $m=\frac{\mathrm{B}-b}{\mathrm{~B}}$ for $\frac{b}{\mathrm{~B}}$ it follows that :

$$
\mathrm{Q}=\mathrm{Cby}{ }^{3 / 2}
$$

where:

$$
\mathrm{C}=f_{s}\left(\mathrm{~F}_{0}, m, \frac{y_{0}}{\mathrm{~B}}\right)
$$

Alternatively :

where

$$
\mathrm{Q}=\mathrm{C}_{l l} b \sqrt{2} g y_{1}^{3 / 2}
$$

$$
\mathrm{C}_{d l}=\frac{\mathrm{C}}{\sqrt{2 g}}
$$

a non-dimensional discharge coefficient.

The discharge coefficient appears thus as a function of the unconstricted flow parameter $\left(F_{0}\right)$, the geometrical proportions of the constric- 
ment non rétréci $\left(y_{0} / B\right)$. Il englobe les effets de la contraction latérale et verticale du jet, ainsi que la correction nécessaire pour tenir compte de la hauteur correspondant à la vitesse d'approche.

Dans le cas limite d'un rétrécissement nul, c'est-à-dire $m=0$, comme :

$$
\mathrm{F}_{0}=\frac{V_{0}}{\sqrt{g y_{0}}}
$$

il vient $y_{1}=y_{0}$ et $b=\mathrm{B}$; donc:

$$
\begin{aligned}
\mathrm{Q}=\mathrm{V}_{0} \mathrm{~B} y_{0} & =\sqrt{g} \mathrm{~F}_{0} B y_{0}{ }^{3 / 2} \\
\mathrm{C} & =\sqrt{g} \mathrm{~F}_{0}
\end{aligned}
$$

Le cas où $m$ est très voisin de l'unité correspond à un écoulement à traver's une fente étroite dans un canal très large. Pour un débit donné Q, la hauteur d'eau dans le remous $y_{1}$ dépassera de loin la profondeur $y_{0}$ de l'écoulement aval et s'en ressentira fort peu, quelle que soit la valeur de $F_{0}$. Il s'ensuit, évidemment, qu’à mesure que $m$ approche de l'unité, $G$ tend à s'affranchir de $\mathrm{F}_{0}$

\section{L'équation de la courbe de remous}

Pour trouver le rapport $y_{1} / y_{0}$ en fonction de C, on divisera l'équation (2) par l'équation (4); on trouvera :

$$
\frac{y_{1}}{y_{0}}=\left(\frac{\sqrt{g} \mathrm{~B} \mathrm{~F}_{0}}{\mathrm{Cb}}\right)^{2 / 3}=\left|\frac{\sqrt{g} \mathrm{~F}_{0}}{\mathrm{C}(1-\cdots m)}\right|^{2 / 3}
$$

Dans le cas de canaux a forle pente raide $\left(F_{0}>1\right)$, l'équation (6) ne s'appliquera que si $y_{1}$ dépasse la profondeur conjuguée du ressaut hydraulique pour les valeurs particulières $y_{0}$ et $\mathbf{F}_{10}$ du canal non rétréci. L'équation du ressaut hydraulique, exprimée en fonction du nombre de Froude de l'écoulement non perturbé [4], donne la condition de stabilité du ressaut:

$$
\frac{y_{1}}{y_{0}} \geqslant \frac{1}{2}\left(\sqrt{1+8 \mathrm{~F}_{0}^{2}}-1\right)
$$

\section{Résultats des expériences}

Les essais ont été effectués dans un canal à pente variable de $81 / 4$ pouces $(21 \mathrm{~cm})$ de largeur avec fond plat en verre. Les faces latérales étaient en bois lisse avec des glaces de deux pieds $(60 \mathrm{~cm})$ de longueur à la hauteur de la section examinée. En général, on cherchait à établir un régime uniforme dans le canal non rétréci et à observer la profondeur $y_{1}$. On introduisait ensuite dans la section d'essai une
Lion $(m)$, and of the unconstricted flow $\left(y_{0} / B\right)$ The coefficient embodies the effects of lateral and vertical contraction of the jet and also the correction for the approach velocity head.

For the limiting case of zero contraction i.e. $m=0$, since :

$y_{1}=y_{0}$, and $b=-\mathrm{B}$,

$$
\mathrm{F}_{0}=\frac{\mathrm{V}_{01}}{\sqrt{g y_{0}}}
$$

$$
\begin{gathered}
\mathrm{Q}=\mathrm{V}_{0} \mathrm{~B} y_{0}=\sqrt{g} \mathrm{~F}_{0} \mathrm{~B} y_{0}^{3 / 2} \\
\mathrm{C}=\sqrt{g} \mathrm{~F}_{0}
\end{gathered}
$$

The case of $m$ very nearly equalling unity corresponds to flow through a narrow slot in a very wide channel. For a given flow rate $Q$, the backwater depth $y_{1}$ will greatly exceed the downstream flow depth $y_{0}$ and will be little affected by its magnitude, whatever the value of $F_{0}$. Evidently, therefore as $m$ approaches unity, $\mathrm{C}$ tends to become independant of $\mathrm{F}_{0}$.

\section{The Backwater Equation}

The backwater ratio, $y_{1} / y_{0}$, expressed in terms of $\mathbf{C}$, follows from the division of $\mathrm{Eq} .(2)$ by El. (4).

$$
\frac{y_{1}}{y_{0}}=\left(\frac{\sqrt{g} B F_{0}}{c b}\right)^{2 / 3}=\left(\frac{\sqrt{g} F_{0}}{c(1-m)}\right)^{2 / 3}
$$

For steep slope channels $\left(\mathrm{F}_{0}>1\right)$, Eq. 6 will apply only if $y_{1}$ exceeds the sequent depth of the hydraulic jump for the particular $y_{0}$ and $F_{0}$ values in the unconstricted channel. From the hydraulic jump equation expressed in terms of the approach flow Froude Number [4], there results the jump stability condition :

$$
\frac{y_{1}}{y_{0}} \geqslant \frac{1}{2}\left[\left(\sqrt{1+8 F_{0}^{2}}-\cdots 1\right)\right]
$$

\section{Experimental Results}

Tests were undertaken in a tilting flume $81 / 4$ in. wide with a plate glass bottom. The sides were of smooth timber except for two foot long glass windows at the test section. The general procedure was to establish a condition of uniform flow in the unconstricted channel and to observe the depth $\left(y_{0}\right)$. A $1 / 8$ in. thick brass constricting plate with sharp vertical edges (See fig. 1 a) was then inserted at the test section 
plaque rétrécissante en laiton de $1 / 8$ pouce $(3,2 \mathrm{~mm})$ d'épaisseur à arêtes verticales vives (fig. $1 a$ ) et on observait la profondeur axiale maximum $y_{1}$, juste en amont du point où le courant commence à plonger vers l'ouverture de la plaque. On modifiait systématiquement le nombre de Froude $F_{0}$ de l'écoulement initial en réglant le débit, la pente et aussi, dans le cas de l'écoulement subcritique, le niveau aval du canal constitué par un volet déversant réglable.

Les essais portaient sur la gamme des valeurs suivantes :

Valeurs du rétrécissement $m=(\mathrm{B}-b) / \mathrm{B} \%$ : $10,20,331 / 3,50,662 / 3,80,90,95$.

Nombres de Froude de l'éconlement initial:

$$
F_{0}=\left(V_{0}\right) / \sqrt{g} y_{0}: 0 \text { à } 2,13 \text {. }
$$

Débits (en pieds cubes):

$$
0,025 \text { à } 0,079\left(0_{3} 0007 \text { à } 0,0022 \mathrm{~m}^{\circ}\right) \text {. }
$$

Profondeur naximum $y_{1}$ :

6 pouces $(15 \mathrm{cml})$

Dans le domaine exploré, le coefficient de débit $G$ variait systématiquement avec $m$ et $F_{0}$; toutefois, aucun effet du rapport $y_{0} / \mathrm{B}$ n'a été noté. La figure 3 représente trois courbes expé- and the maximum centre-line depth $\left(y_{1}\right)$ just upstream of the commencement of drawdown to the plate opening was observed. The unconstricted flow Froude Number, $F_{0}$, was varied hy adjustment of the discharge, the channel till and, for suberitical flow, the channel outlet control, which was a sharp crested weir of adjustable height.

The range of the tests was as follows: Constriction ratios $m=(\mathrm{B}-b) / \mathrm{B} \%$ :

$10,20,331 / 3,50,662 / 3,80,90,95$.

Unconstricted flow Froude Numbers :

$$
F_{0}==\left(V_{0}\right) / \sqrt{g} y_{0}: 0 \text { to } 2.13
$$

Flow rales (efs):

0.025 to 0.079 .

Maximum depth, $y_{1}$ :

6 inches.

Within the range of the tests, the discharge coefficient $C$ was found to vary systematically with $m$ and $F_{0}$ but no ellect of the ratio $y_{0} / \mathrm{B}$ was detected. Three typical experimental curves $\left(m=10,50\right.$ and $90 \%$ ) for $\mathrm{C}$ as a function of $\mathrm{F}_{0}$ are shown in fig. 3. Instability of the flow at
Fili. 3

Courbes experimentales typiques donnant $C$ en fonction de $F$, et de $m$.

Typical experimental curves showing $G$ as a function of $F_{0}$ and $\mathrm{m}$.

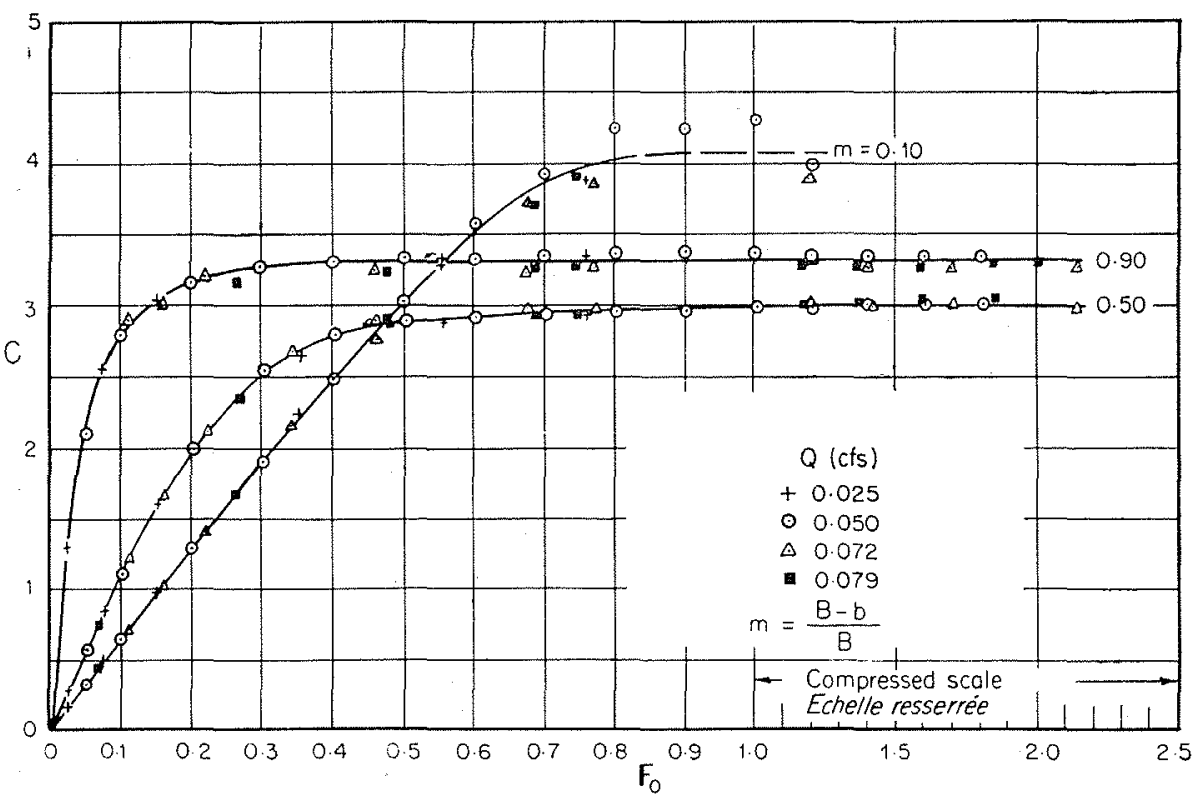

rimentales typiques $(m=10,50$ et $90 \%)$ donnant $\mathrm{C}$ en fonction de $\mathrm{F}_{0}$. L'instabilité du courant aux nombres de Froude élevés, due au voisinage du ressaut hy"draulique, créait une certaine dispersion des valeurs de la courbe $m=10 \%$. Les courbes correspondant à toutes les plaques rétrécissantes sont réunies sur la fi- high Froude Numbers due to the proximity of the hydraulic jump produced some scatter in the $m=10 \%$ curve. The curves for all constriction plates are shown in fig. $4(\alpha)$, the experimental points having been omitted for the sake of clarity. For any particular value of $m$, c increases initially with $F_{9}$, becoming sensibly 
gure $4 a$, où les points expérimentaux ont été omis pour des raisons de clarté. Pour chacune des valeurs particulières de $m$, $C$ commence par augmenter avec $F_{0}$, devenant sensiblement constant au-delà d'une certaine valeur limite de $\mathrm{F}_{0}$, valeur mal définie nettement, qui décroit quand augmente $m$. Comme il a été indiqué cidessus, quand $m$ est très voisin de l'unité, Cidevient pratiquement indépendant de $F_{0}$. La variation des valeurs extrèmes de $\mathrm{C}$ en fonction de $m$ est portée sur la figure $4 \mathrm{~b}$. La forme de la courbe traduit les influences antagonistes qu'exercent sur $\mathrm{C}$, à mesure qu'augimente $m$, les accroissements des contractions latérale et ver- constant beyond a limiting value of $F_{0}$. This limiting value, which is not sharply defined, decreases with increase of $m$. As previously surmised, it appears that, with $m$ very nearly equal to unity, $C$ becomes practically independent of $F_{0}$. The variation of the ultimate $C$ values with $m$ is plotted in fig. $4(b)$. The form of the curve reflects the opposing influences on $c$, with increase on $m$, of the increases in the lateral and vertical contraction and of the decrease in depth of water behind the conslricting plate.

From fig. $4(c)$ the condition of the flow up-

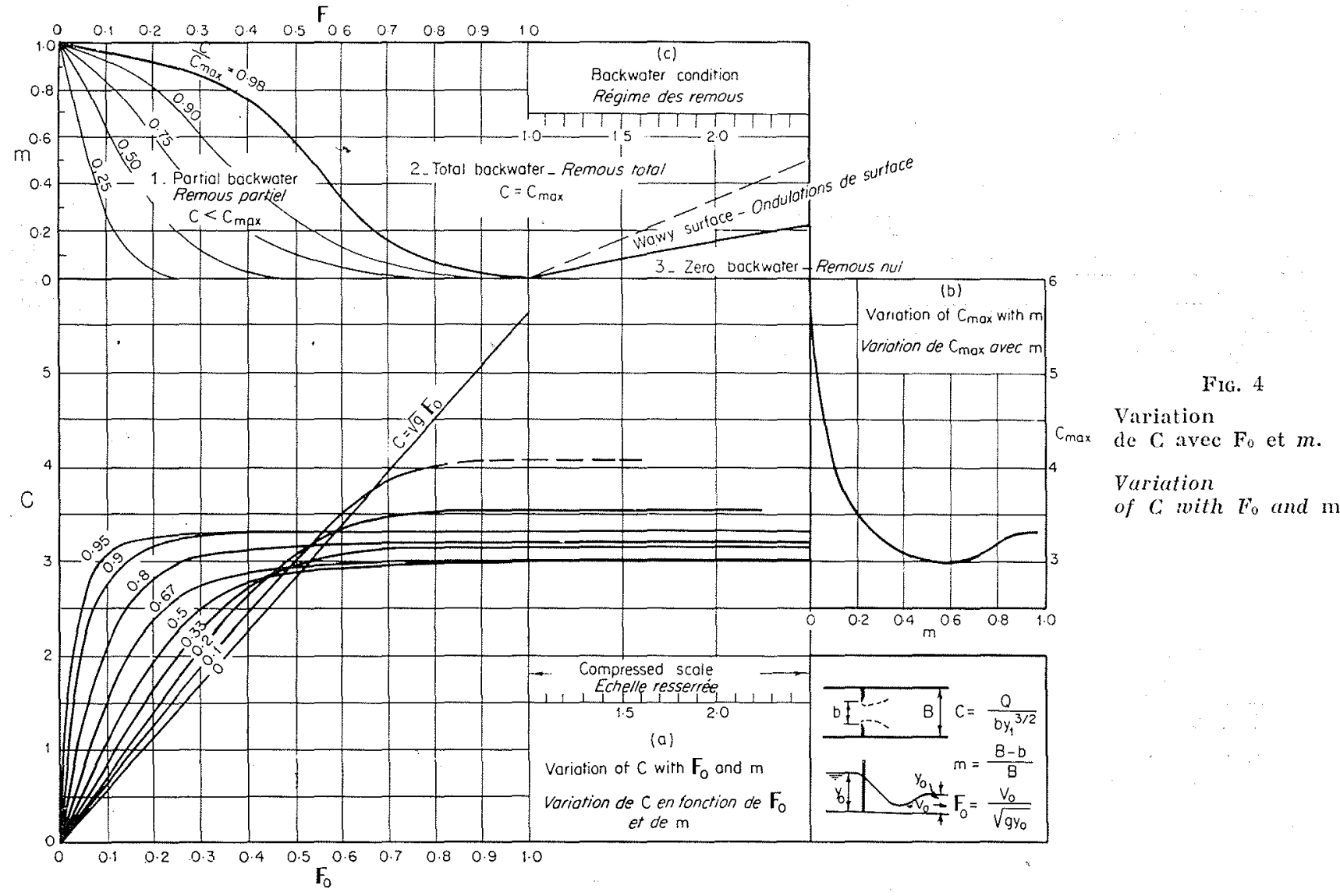

ticale et, dautre part, la diminution de la profondeur de l'eau derrière la plaque rétrécissante.

A l'aide de la figure $4 c$, on pourra déterminer les conditions d'écoulement en amont de la section rétrécie pour différentes combinaisons de $m$ et de $F_{0}$. La région 1 correspond à un régime à remous « partiel », $\mathrm{C}$ étant inférieur à $\mathrm{C}_{\operatorname{mix}}$; comme limite supérieure, on a adopté arbitrairement celle pour laquelle $\mathrm{C}=0,98 \mathrm{C}_{\max }$. La région 2 correspond à un régime à remous « établi », C étant égal à $\mathrm{C}_{\mathrm{m} a x}$. A la partic supérieure de cette zone, il apparait immédiatement en stream of the constriction can be determined for various combinations of $m$ and $F_{0}$. Region 1 corresponds to "partial " backwater conditions, that is, with $C$ less than $C_{\max }$, the upper limit being arbitrarily adopted as that for which $\mathrm{C}=0.98 \mathrm{C}_{\max }$. Region 2 corresponds to "complete" backwater conditions, with $\mathrm{C}$ equal to $\mathrm{C}_{\mathrm{max}}$. In portion of this region, the effects of the hydraulic jump just upstream result in a wavy surface near the plate and consequent instability of the flow through the constriction. Region 3 corresponds to zero backwater, the flow up- 
amont du ressaut, près de la plaque, des ondulations provoquant une instabilité de l'écoulement dans la section rétrécie. La région 3 correspond à un régime à remous nul; l'écoulement en amont de la plaque est uniforme et supercritique. stream of the plate being uniform and supercritical.

The variation of the backwater ratio $y_{1} / y_{0}$ with $F_{0}$ and $m$ is shown in fig. 5. To the right of the broken line, the values of the discharge coef-

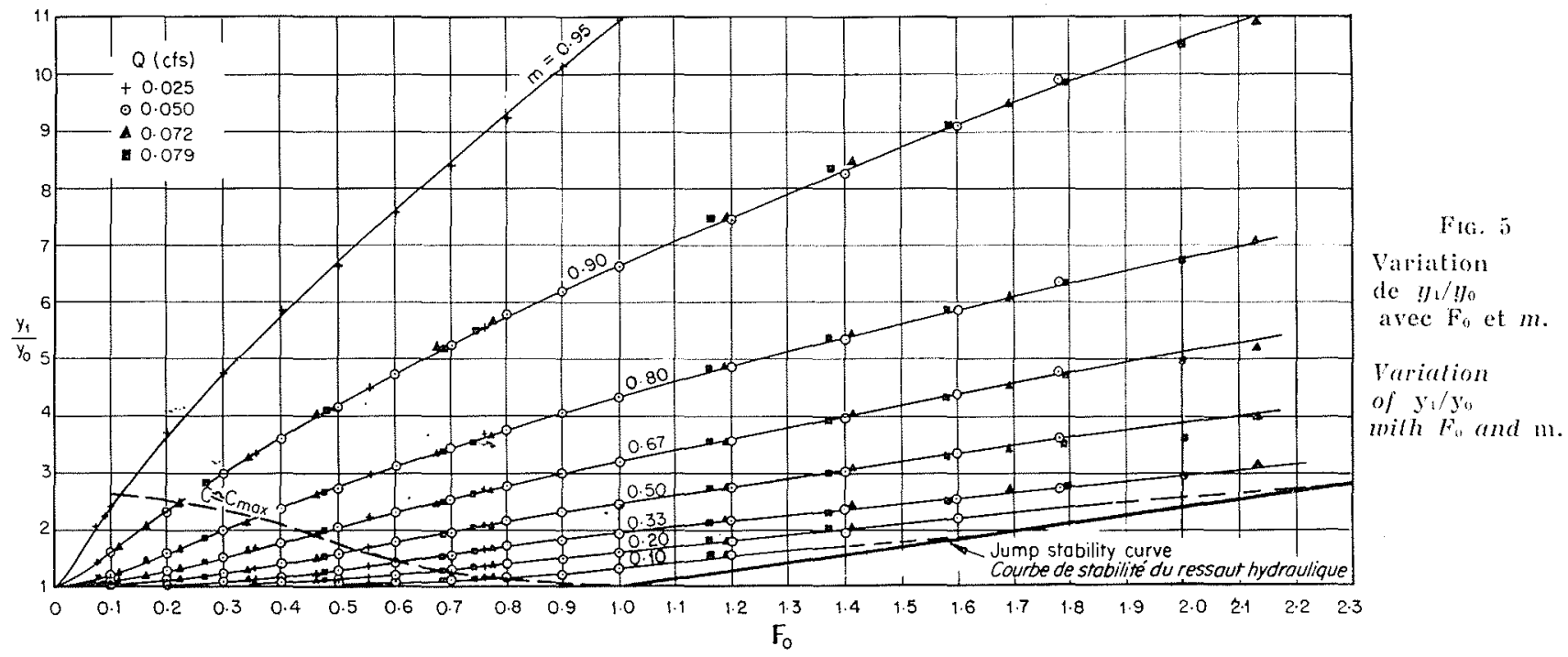

Fic, 6

Variation de $y_{1} / y_{0}$ avec $F_{0}$ et $m$ pour les faibles valeurs de $F_{0}$.

Variation of $\mathrm{y}_{1} / \mathrm{y}_{0}$ with $F_{0}$ and $\mathrm{m}$

for small values of $F_{0}$.

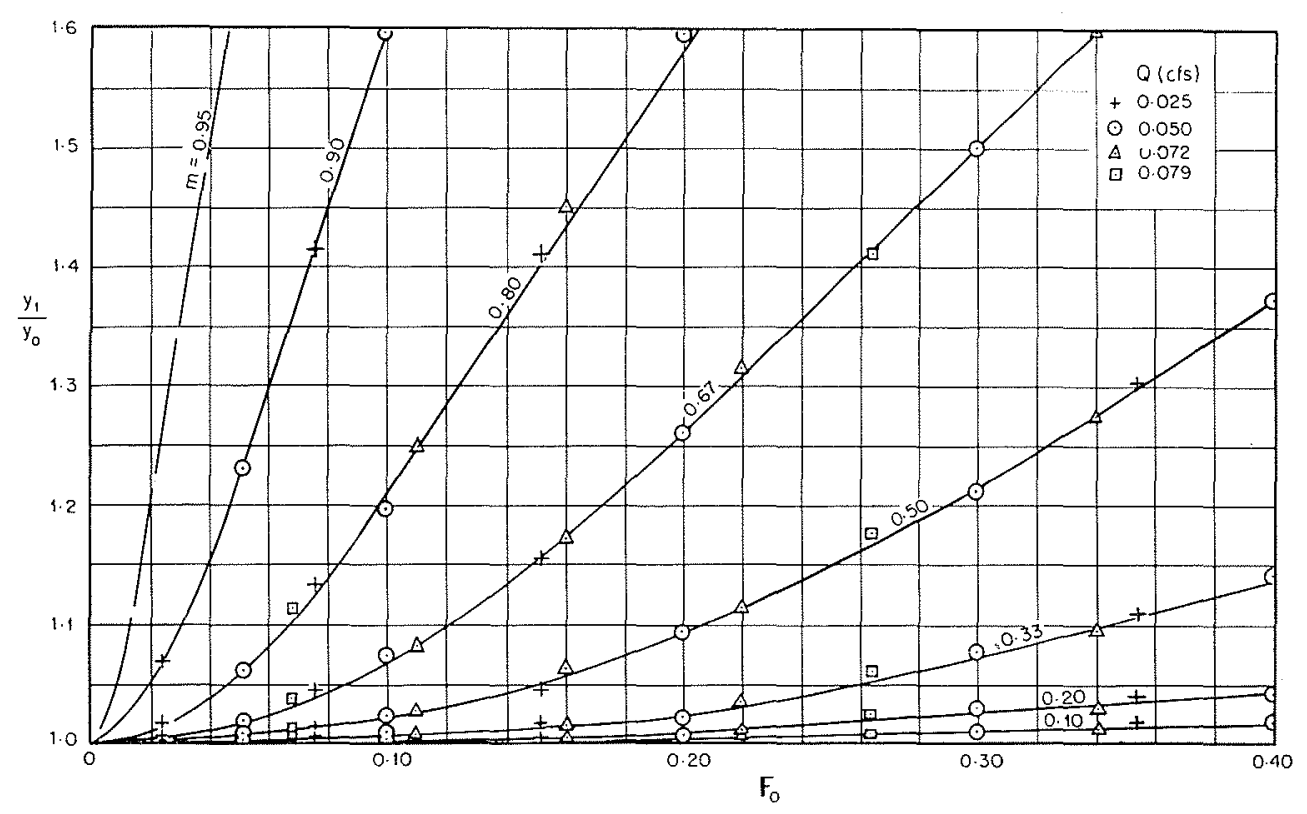

La figure 5 montre la variation du rapport $y_{1} / y_{0}$ avec $\mathrm{F}_{0}$ et $m$. A droite de la ligne brisée, les coefficients de déhit correspondant aux courbes $n$ respectives sont constants, e'est-à-dire on a $\mathrm{C}=\mathrm{C}_{\max }$. Les courbes $m$ inférieures s'adossent à la courbe en traits pleins (éc. 7) représentant le critérium de stabilité du ressaut hydraulique. La figure 6 représente à plus grande ficients for the respective $m$ curves are constant, that is $\mathrm{C}=\mathrm{C}_{\max }$. The lower m-curves terminate at the heavy line (Eq. 7) which represents the criterion for stability of the hydraulic jump. Figure 6 shows, to an enlarged scale, the $y_{1} / y_{0}$ v. $F_{0}$ relationship for values of $F_{0}$ less than 0.4 .

In fig. 7, the curves of fig. 5 are partly unified 


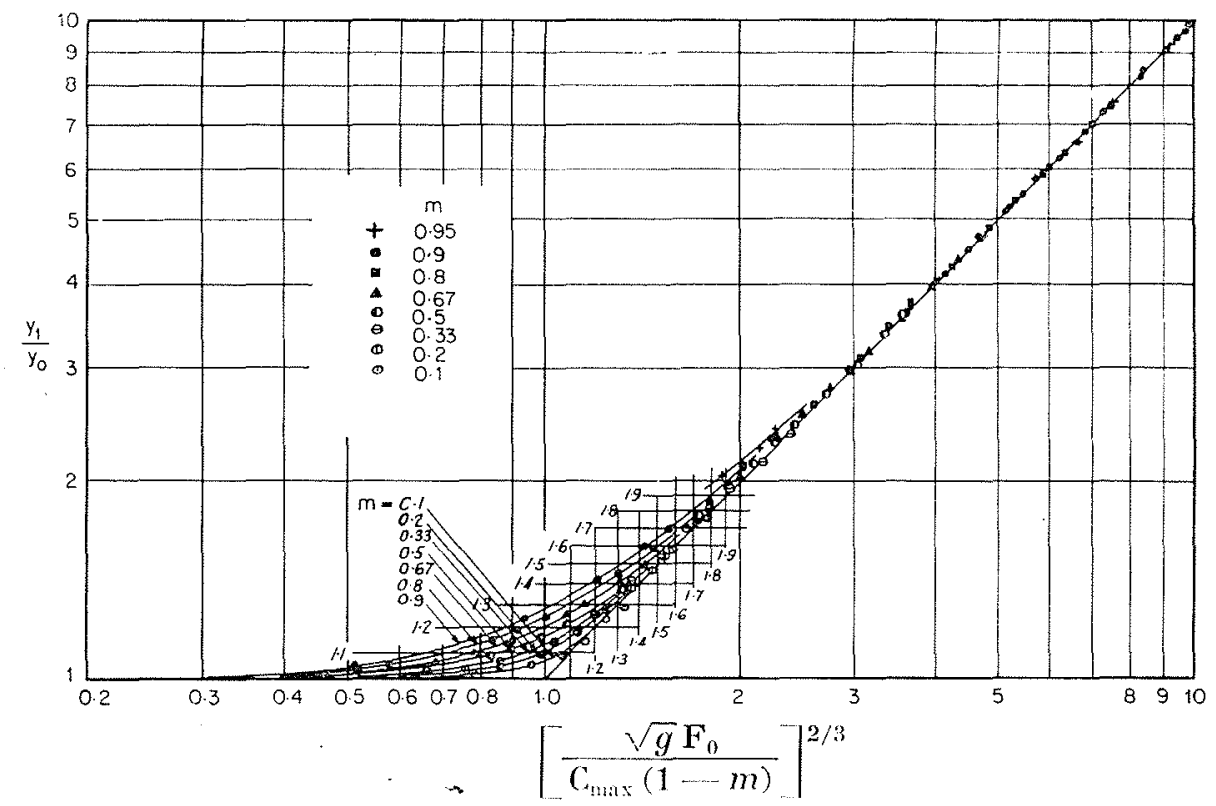

FIti. 7

ichelle la relation entre $y_{1} / y_{0}$ et $\mathrm{F}_{0}$ pour des $\mathrm{F}_{0}<0,4$.

Sur la figure 7 , les courbes de la figure 5 sont en partie réunies en un seul diagramme basé sur l'équation (4), les valeurs adoptées pour C. élant des' maxima corréspondant aux différents coefficients de restriction, comme il est représenté sur la figure $4 \mathrm{~b}$.

\section{Conclusions}

Le débit à travers une fente verticale à arête vive perpendiculaire à l'écoulement dans un canal rectangulaire peut ètre exprimé par $\mathrm{Q}=\mathrm{C} b y_{1}^{3 / 2}$ où $\mathrm{C}$ est une fonction de $m$ et de $\mathrm{F}_{0}$ déterminée expérimentalement.

$Q$ et les caractéristiques du canal (donc aussi $F_{0}$ ) étant connus, l'équation donnera la hauteur du remous $y_{1}$. Connaissant $y_{1}$ et les caractéristiques du canal, on pourra déterminer $Q$ d'après cette équation par approximations successives en partant d'une première estimation de $F_{0}$ à laquelle on superpose des corrections successives.

$y_{1}$ et $y_{0}$ étant connus, le diagramme des hauleurs conjuguées (fig. 5 et 6 ) donnera la valeur correspondante de $F_{0}$ d'où l'on déduira:

$$
\mathrm{Q}=\mathrm{B} \vee \mathrm{g} y_{0}^{3 / 2} \mathrm{~F}_{0} \text {. }
$$

in a graph based upon Eq. 4, the values adopted for $C$ being the maximum values for the respeclive constriction ratios, as shown in fig. $4(b)$.

\section{Conclusion}

The discharge through a sharp edged vertical slot set normal to the flow in a smooth rectangular channel can be expressed as $Q=C b y_{1}{ }^{3 / 2}$ where $\mathrm{C}$ is a function of $m$ and $\mathrm{F}_{0}$, determined experimentally.

If $Q$ and the channel properties (and hence $F_{0}$ ) are known, this equation will yield the backwater depth $y_{1}$. If $y_{1}$ and the channel properlies are known, $Q$ can be determined from the equation by means of successive approximations, following an initial estimate of, and subsequent corrections to, the value of $F_{0}$.

If $y_{1}$ and $y_{0}$ are known, the graph of the backwater ratio (figs. 5 and 6 ) yields the corresponding value of $\mathrm{F}_{0}$, whenee :

$$
\mathrm{Q}=\mathrm{B} \sqrt{g} y_{0}{ }^{3 / 2} \mathrm{~F}_{0} .
$$

\section{REFERENCES}

1. YARxel (D, L.) (1934) "Bridge Piers as Channel Obstructions." U. S. Dept. Agric., Tech. Bulletin No. 4.42 .

2. Kindsvater (C. E.) and Capter (R. W.) (1955) "Tranquil Flow through Open Channel Constrictions." Trans. ASCE, Vol. 120, p. 955.
3. Tracy (J. T.) and Carter (R. W.) (1955) "Backwater Effects of Open Channel Constrictions." Trans. $A S C E$, Vol. 120 , p. 993 .

4. BAKHMETEFF (B. A.) (1932) "Hydraulics of Open Channels." (McGr(lu-Hill). 